\title{
Relationship of Fecundity and different body parameters of Clarias magur (Hamilton, 1822) in captive condition in the Agro climatic condition of Assam, India
}

\author{
Arup Buragohain ${ }^{1}$, M. M. Goswami ${ }^{2}$ \\ ${ }^{1,2}$ Department of Zoology, Fish Biology and Fishery Science, Gauhati University, Guwahati -781014, \\ Assam,India.
}

\begin{abstract}
Fecundity of an indigenous Indian cat fish Clarias magur (Hamilton, 1822) during spawning season (April to July, 2011) has been studied. Relationship of fecundity $(F)$ with body weight $(B W)$, total length $(T L)$, ovary length $(O L)$, ovary weight $(O W)$, gonadosomatic index $(G S I \%)$ and ova diameter $(O D)$ was calculated. Fecundity is found to be the lowest $(3947.91 \pm 506.42)$ in the month of April and the highest (10957.47 \pm $3031.49)$ in the month of June. The value of Correlation coefficient $(r)$ between $F$ and $B W$ is highly significant $(r=0.95)$ followed by $F$ and $O W(r=0.88)>F$ and $O L(r=0.74)>F$ and $T L(r=0.60)$ and $>F$ and $G S I(r=0.51)$. The correlation between with $F$ and $O D$ has not shown significant correlationship (0.09). Fecundity exhibits the highest correlationship (r) with $B W, O W, T L$ and GSI during the month of June.
\end{abstract}

Key words: Clarias magur, Fecundity and Correlation coefficient.

\section{Introduction:}

The walking cat fish Clarias magur (Hamilton, 1822) locally known as 'Magur' is a highly priced air-breathing cat fish distributed in Ganga and Brahmaputra river basins of northern and northeastern India, Nepal, Bhutan and Bangladesh [1]. The species belonging to the order Siluriformes and family Clariidae under class Osteichthyes and subclass-Actinopterygii is one of the most potential cultivable cat fish species. Clarias magur is considered as endangered fish species according to IUCN red data list [2].The population of this species is declining day by day due to drying up of wetlands, use of pesticides in the paddy field and overfishing. Due to non-availability of quantity and quality seeds from wild and natural source and also scarcity of matured brood fish which is the major constraint in the culture of this species in a large scale level. To overcome this bottleneck of seeding production and culture as well in pond environment through induced breeding a clear knowledge of gonadosomatic index and fecundity are considered a prerequisite in successful cultivation of a fish. Size and weight of gonad gives a good indication of breeding season of any species in natural environment. The fecundity is termed as number of eggs contained in ovary of a fish [3]. Fecundity has a significance relationship with the natural environment accorded to eggs [4]. In fishery, for evaluating the commercial potentialities of its stock, life history, practical culture and actual management, an adequate knowledge about fecundity is necessary [5][6]. Fecundity also determines the index of density dependent factor affecting the population size [7]. Fecundity, size of the eggs and weight of the ovary of a fish are interrelated in life history traits that have commonly been used to characterized different populations of fishes [8][9].Various factors like changing environment, length, age etc. were responsible in variation on fecundity from one species to another. In the agro-climatic condition of Assam little information is available on the fecundity of Clarias magur.

The present work was undertaken to establish relationship between fecundity (F) with body weight (BW), total length (TL), ovary length (OL), ovary weight (OW), gonadosomatic index (GSI) and ova diameter (OD). Finding and observation of the present study will be helpful for studying population dynamics, further research on induced breeding, seed production and propagation of Clarias magur in Assam, India.

II.I Study area:

\section{Materials and Methods:}

The present work has been conducted in 'Aquaculture and Biodiversity' of UGC-SAP (DRS) project site located at Gauhati University Campus, Guwahati, $\left(26^{\circ} 09^{\prime} 26^{\prime \prime} \mathrm{N}\right.$ and longitude of $\left.91^{\circ} 40^{\prime} 21^{\prime \prime} \mathrm{E}\right)$, Assam, India.

\section{II.2 Brood fish rearing:}

A total of eighty (80) fishes were reared before three (3) months in eight (8) concrete circular cisterns $\left(7.69 \mathrm{~m}^{3}\right)$, each having 10 samples in the cistern and thirty-seven (37) fishes were collected to study the fecundity during the maturity and breeding seasons from April through July, 2011. The fishes were fed with chicken egg protein and trash fish alternately at a rate of $5 \% \mathrm{BW}$ every day. The male and female fishes were separated based on the structure of the genital papilla. In case of male, the papilla was pointed and in female, it was rounded in the form 
of oval vent. The fully ripen females had soft bulging abdomen due to possession of mature eggs. The required numbers of fishes were collected month wise during April to July (Table 1) and anaesthetized by using MS-222 (tricainemethanesulfonate). The samples were washed thoroughly in filtered iron free water and dried the body by removing excess water using blotting paper before taking the measurement of body weight (BW) and total length (TL) was taken with the help of digital balance (nearest to $0.01 \mathrm{~g}$ ) and digital vernier caliper (nearest to $0.01 \mathrm{~mm}$ ) respectively. The ovary weight $(\mathrm{OW})$ and ovary length $(\mathrm{OL})$ were measured in digital balance (nearest to $0.01 \mathrm{gm}$ ) and digital vernier caliper (nearest to $0.01 \mathrm{~mm}$ ) respectively after sacrificing the specimens. For fecundity study one gram from the three cross sectional samples were taken from anterior, middle and posterior position of the two lobes of each ovary and the pieces were kept in Gilson's fluid separately for 2 months to loosen the eggs. The eggs were counted and then the mean number of ova was calculated [10][11][12][13].The total number of eggs in the entire ovary was calculated by multiplying the mean of the sub samples with total weight of the ovary. The diameters of the ova were measured by using bright field LEICA microscope of 15 randomly selected eggs per female sample. For the estimation of gonadosomatic index (GSI) and fecundity following formula is expressed follows:

$\operatorname{GSI}(\%)=\frac{\mathrm{OW} \times 100}{\mathrm{BW}}$

Fecundity $=$ Number of egg in $1 \mathrm{~g}$ of ovary $\times$ total ovary weight $(\mathrm{g})$

The linear relationship between the fecundity of the fish and the six parameter i.e body weight, total length, ovary length, ovary weight and ova diameter was calculated individually by applying the regression equation:

$\mathrm{Y}=\mathrm{a}+\mathrm{bX}$.

Where, $\mathrm{Y}=$ Fecundity $(\mathrm{F}), \mathrm{X}=\mathrm{BW}, \mathrm{TL}, \mathrm{OL}, \mathrm{OW}, \mathrm{GSI}$ and $\mathrm{OD}, \mathrm{a}$ and $\mathrm{b}$ are constants.

The Correlation coefficient and mean \pm SD of all parameter were calculated with the help of SPSS software (version-16) and Microsoft excel.

\section{Results:}

III.I Relationship between fecundity with body weight (BW) and total length (TL):

Distinct egg mass development in the gonad of Clarias magur is observed during April, 2011. The fecundity (F)

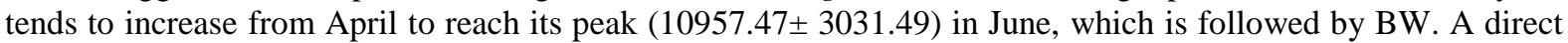
co-relation of $\mathrm{F}$ with $\mathrm{BW}$ is observed throughout the breeding period while it establishes the highest level of significance $(\mathrm{p}<0.05)$ during June (Table 1). The regression graphs (Fig.1a - 1d) also show a clearly positive relationship in June and found to deviate in the other months.

Similar trend is observed between the F and TL. Fecundity does not show significant co-relation with TL in all other months rather than June (0.60) (Table 2).The regression graph (Fig. 2a - 2d) also shows a positive relation but most clearly in June, 2011.

Table. 1: Monthly variation of mean \pm SD of $F$ and $B W$ and value of Correlation coefficient ' $r$ '.

\begin{tabular}{|l|c|c|c|c|c|}
\hline \multicolumn{1}{|c|}{ Months } & Fecundity range & $\begin{array}{c}\text { Body Weight } \\
\text { range(g) }\end{array}$ & Mean \pm SD (F) & Mean \pm SD BW(g) & value of 'r' \\
\hline $\begin{array}{l}\text { April,2011 } \\
\text { N=10 }\end{array}$ & $2829.90-4751.58$ & $95-200$ & $3947.91 \pm 506.42$ & $128.81 \pm 36.89$ & 0.18 \\
\hline $\begin{array}{l}\text { May,2011 } \\
\mathrm{N}=8\end{array}$ & $4394-5770.53$ & $105-192$ & $5292.31 \pm 464.25$ & $144.37 \pm 36.87$ & 0.47 \\
\hline $\begin{array}{l}\text { June,2011 } \\
\mathrm{N}=9\end{array}$ & $7865.04-16607.13$ & $113-200$ & $10957.47 \pm 3031.49$ & $146.02 \pm 30.72$ & $0.95^{*}$ \\
\hline $\begin{array}{l}\text { July,2011 } \\
\text { N=10 }\end{array}$ & $3594.38-7749.45$ & $98-195$ & $6021.023 \pm 1571.54$ & $152.1 \pm 32.91$ & 0.21 \\
\hline
\end{tabular}

* correlation is significant at 0.05 level (2-tailed)

Table. 2: Monthly variation of mean \pm SD of F and TL and value of Correlation coefficient ' $r$ '.

\begin{tabular}{|l|l|l|l|l|}
\hline Months & $\begin{array}{l}\text { Total length } \\
\text { range }(\mathrm{cm})\end{array}$ & Mean \pm SD $(\mathrm{F})$ & Mean \pm SD TL(cm) & value of ' $\mathrm{r}$ ' \\
\hline April,2011 & $22.1-29$ & $3947.91 \pm 506.42$ & $24.26 \pm 2.03$ & 0.45 \\
\hline May,2011 & $24-27$ & $5292.31 \pm 464.25$ & $24.21 \pm 1.41$ & 0.42 \\
\hline June,2011 & $22.6-28.5$ & $10957.47 \pm 3031.49$ & $24.83 \pm 1.72$ & 0.60 \\
\hline July,2011 & $22.2-25.1$ & $6021.02 \pm 1571.54$ & $23.88 \pm 0.91$ & 0.36 \\
\hline
\end{tabular}


III.2 Relationship between fecundity with ovary length $(\mathrm{OL})$ and ovary weight $(\mathrm{OW})$ :

Significant co-relation between F and OL $(\mathrm{p}<0.05)$ ) attributed in the month of May but it shows negative corelation in April (-0.20) and poorly significant in June (Table 3). It maintains a weak positive co-relation with OL during the other months and not found to be significant. The regression (Fig. 3a-3d) indicates a negative relation in April and July, positive in May and June, 2011.

During the study period (April to July, 2011) weight of the ovary increases gradually from April reaching its peak $(13.95 \pm 4.28)$ in June and thereafter decreases in July. The correlation coefficient between Fecundity and ovary weight is highly significant $(\mathrm{p}<0.05))$ in the month of June and does not show positive correlation during other months (Table. 4) and as shown in the regression graphs (Fig. $4 \mathrm{a}-4 \mathrm{~d}$ ).

Table. 3: Monthly variation of mean \pm SD of Fand OL and value of Correlation coefficient ' $r$ '.

\begin{tabular}{|l|l|l|l|l|}
\hline Months & $\begin{array}{l}\text { ovary length range } \\
(\mathrm{cm})\end{array}$ & Mean \pm SD (F) & Mean \pm SD OL(g) & value of 'r' \\
\hline April,2011 & $3.6-6.7$ & $3947.91 \pm 506.42$ & $4.97 \pm 0.89$ & -0.20 \\
\hline May,2011 & $4.2-7.1$ & $5292.31 \pm 464.25$ & $5.65 \pm 0.95$ & $0.74^{*}$ \\
\hline June,2011 & $5.1-9.1$ & $10957.47 \pm 3031.49$ & $6.9 \pm 1.27$ & 0.50 \\
\hline July,2011 & $4.8-7.8$ & $6021.02 \pm 1571.54$ & $6.3 \pm 0.81$ & 0.02 \\
\hline
\end{tabular}

* correlation is significant at 0.05 level (2-tailed)

Table. 4: Monthly variation of mean \pm standard deviation (SD) of Fecundity and ovary weight $(\mathrm{OW})$ and value of Correlation coefficient ' $r$ '.

\begin{tabular}{|l|l|l|l|l|}
\hline Months & Ovary weight range $(\mathrm{g})$ & Mean \pm SD $(\mathrm{F})$ & Mean \pm SD OW $(\mathrm{g})$ & value of ' $\mathrm{r}$ ' \\
\hline April,2011 & $3.46-10.78$ & $3947.91 \pm 506.42$ & $7.93 \pm 2.47$ & 0.21 \\
\hline May,2011 & $5.2-16.45$ & $5292.31 \pm 464.25$ & $11.03 \pm 3.97$ & 0.68 \\
\hline June,2011 & $8-20.14$ & $10957.47 \pm 3031.49$ & $13.95 \pm 4.28$ & $0.88^{*}$ \\
\hline July,2011 & $8.72-21.01$ & $6021.02 \pm 1571.54$ & $12.76 \pm 3.74$ & 0.57 \\
\hline
\end{tabular}

*correlation is significant at 0.05 level (2-tailed)

III.3 Relationship between fecundity with gonadosomatic index\% and ova diameter:

There exhibits no positive correlation between F and GSI\% during the study period as shown in the regression graph (Fig.5 a -5 d) and Table 5.

A negative correlation exists between $\mathrm{F}$ and $\mathrm{OD}$ in the month of June $(\mathrm{p}<0.05)$ ) but no correlation exhibits in the others months during the study period as shown in the regression graph (Fig.6 a $-6 \mathrm{~d}$ ) and Table 6 .

Table. 5: Monthly variation of mean \pm standard deviation (SD) of Fecundity and gonadosomatic index (GSI\%) and value of Correlation coefficient ' $r$ '.

\begin{tabular}{|l|l|l|l|l|}
\hline Months & $\begin{array}{l}\text { Gonadosomatic index } \\
\text { range\% }\end{array}$ & Mean \pm SD (F) & Mean \pm SD GSI\% & value of 'r' \\
\hline April,2011 & $3.64-10.67$ & $3947.91 \pm 506.42$ & $6.42 \pm 2.52$ & 0.09 \\
\hline May,2011 & $4.95-13.75$ & $5292.31 \pm 464.25$ & $7.90 \pm 3.26$ & 0.39 \\
\hline June,2011 & $7.07-12.57$ & $10957.47 \pm 3031.49$ & $9.43 \pm 1.61$ & 0.51 \\
\hline July,2011 & $6.01-12.57$ & $6021.02 \pm 1571.54$ & $8.63 \pm 2.63$ & 0.35 \\
\hline
\end{tabular}


Relationship of Fecundity and different body parameters of Clariasmagur (Hamilton, 1822) in

Table. 6: Monthly variation of mean \pm standard deviation (SD) of Fecundity and ova diameter (OD), value of Correlation coefficient ' $r$ '.

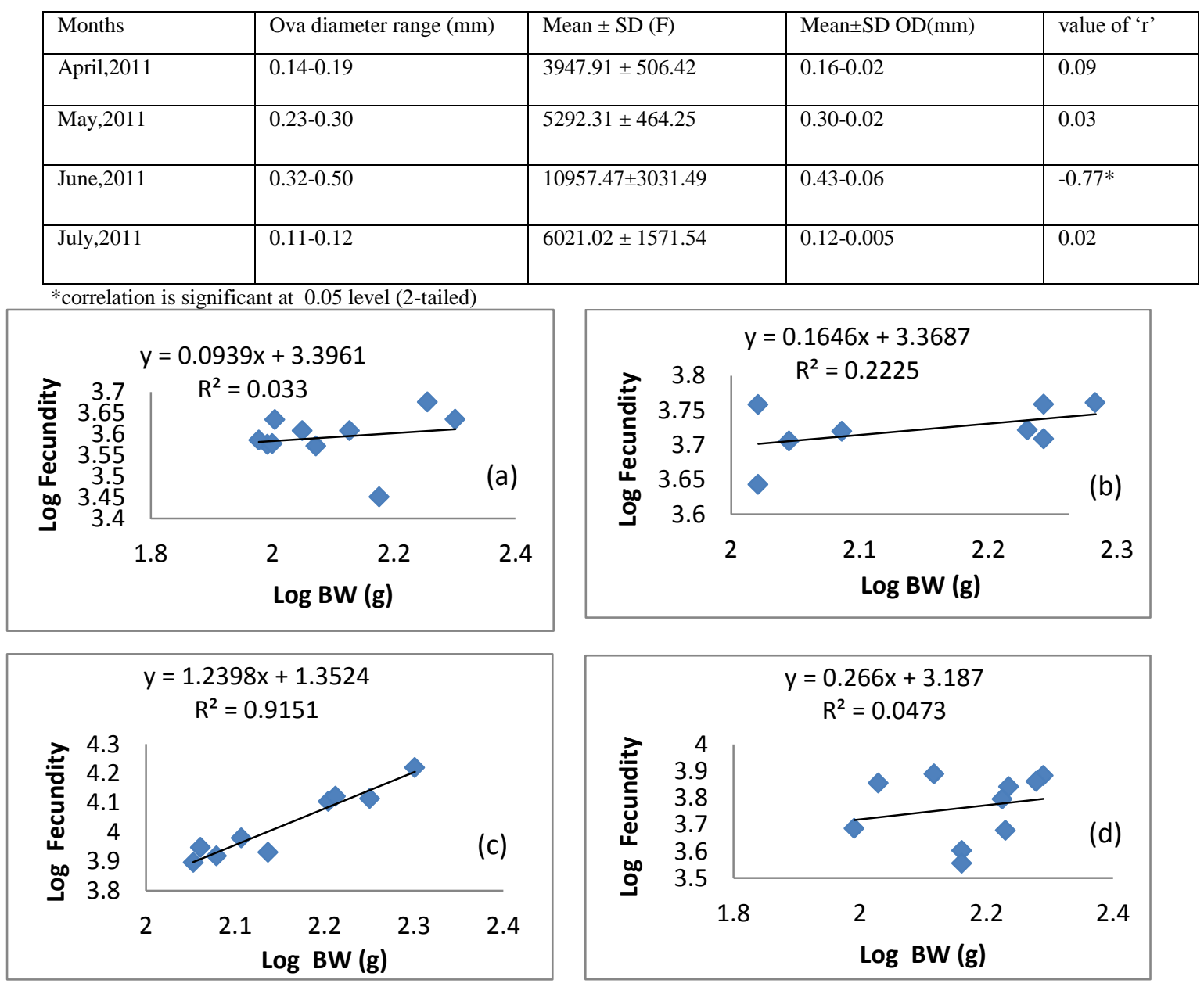

Fig. 1 (a) - (d): Relationship between Log Fecundity and Log body weight of Clarias magur during April to July, 2011.
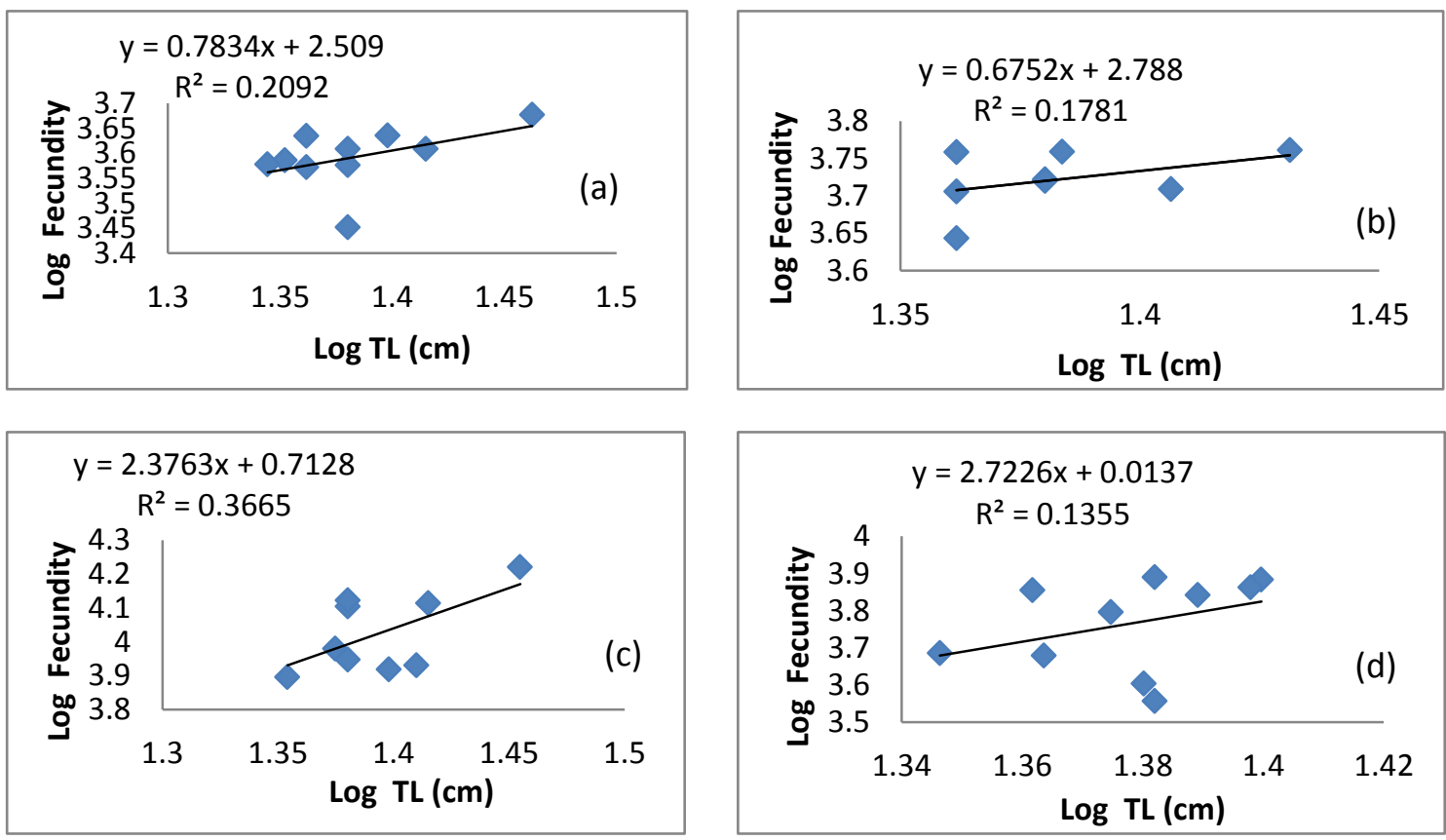
Fig. 2 (a) - (d): Relationship between Log Fecundity (F) and Log total length (TL) of Clarias magur during April to July, 2011.
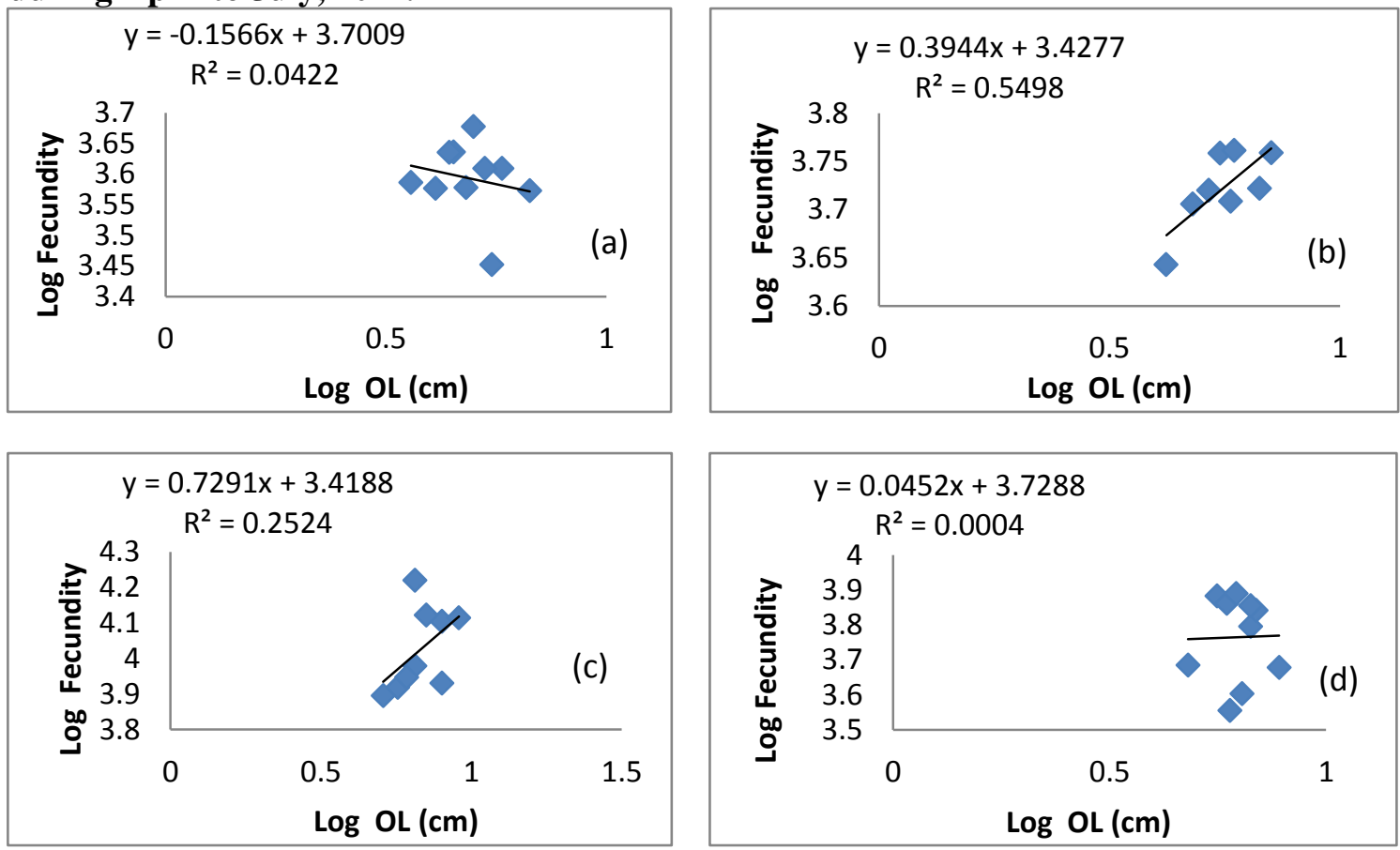

Fig. 3 (a) - (d):Relationship between Log Fecundity (F) and Log ovary length (OL) of Clarias magur during April to July, 2011.
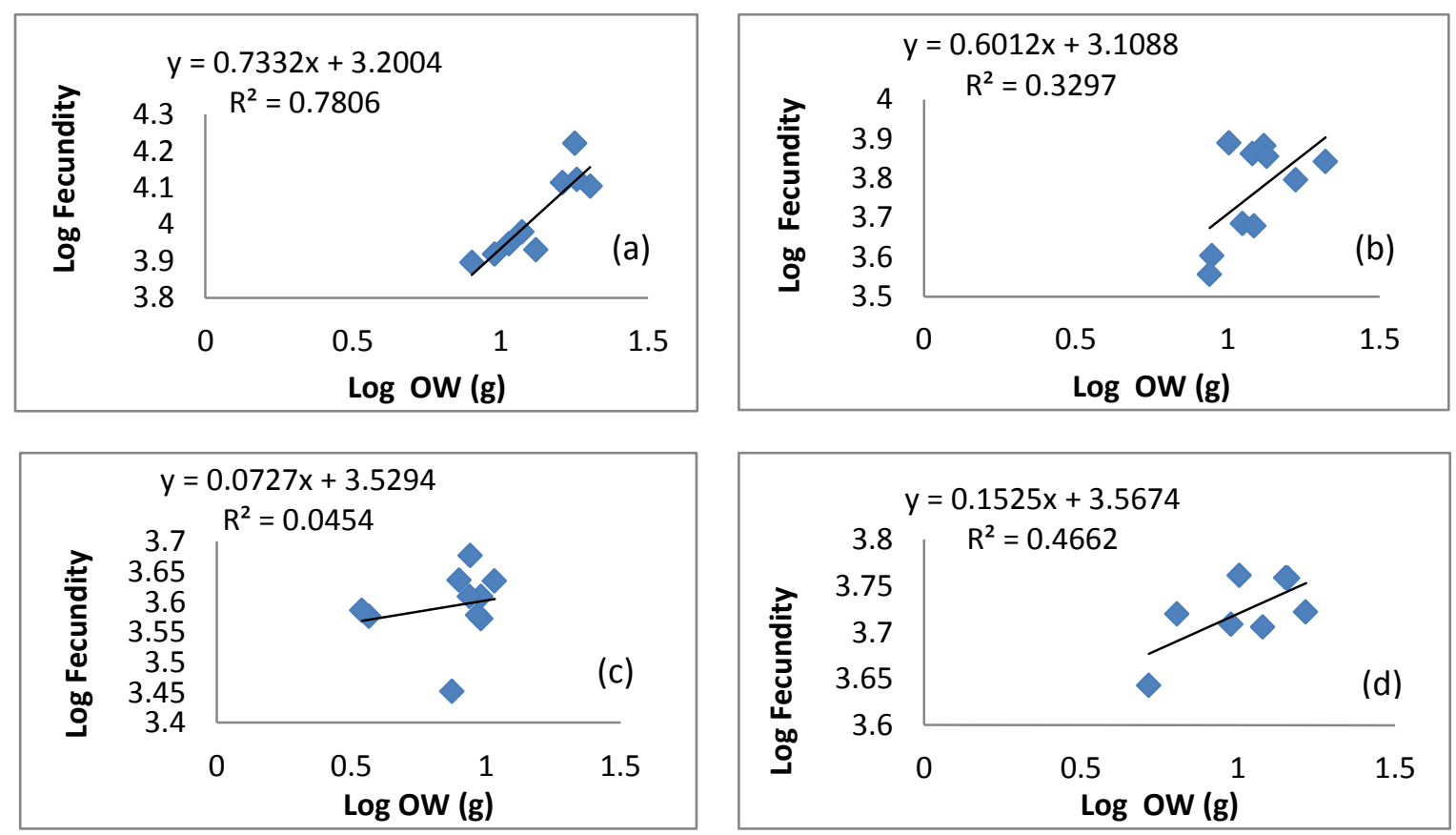

Fig. 4 (a) - (d): Relationship between Log Fecundity (F) and Log ovary weight (OW) of Clarias magur during April to July, 2011. 

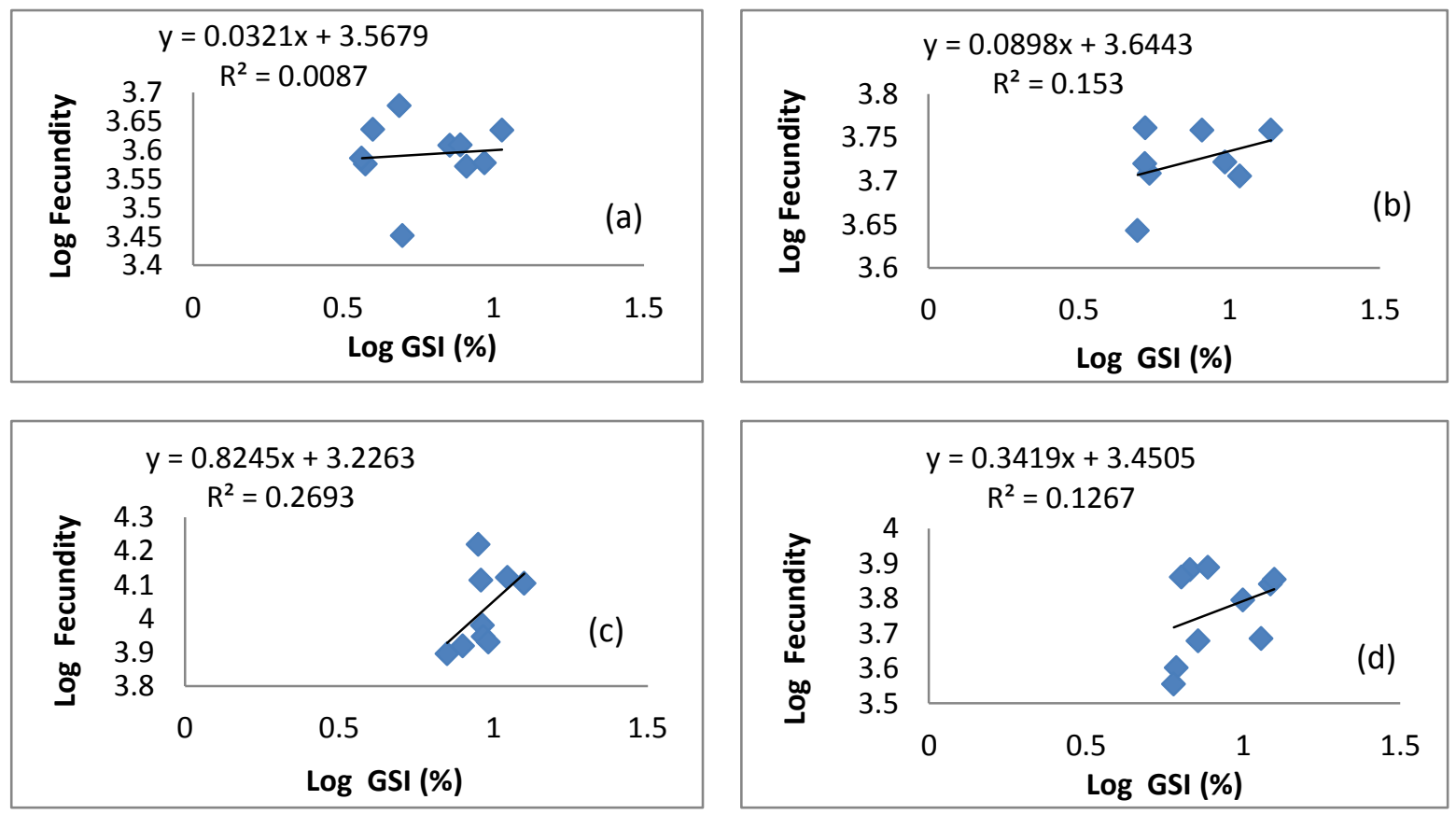

Fig. 5 (a) - (d): Relationship between Log Fecundity (F) and Log gonadosomatic index (GSI\%) of Clarias magur during April to July, 2011.
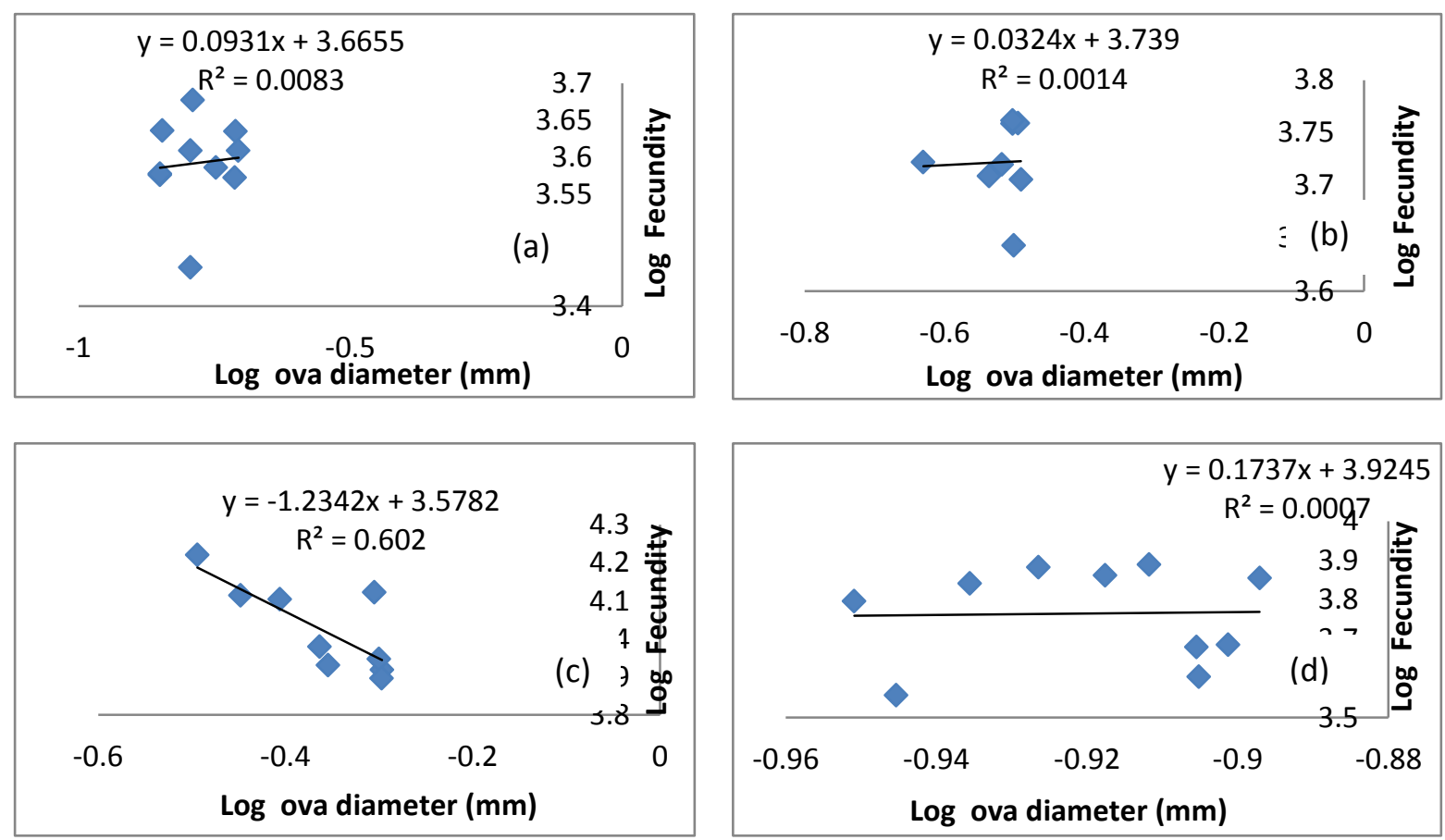

Fig. 6 (a) - (d): Relationship between Log Fecundity (F) and Log ova diameter (OD) of Clariasmagur during April to July, 2011.

\section{Discussion:}

Understanding of the reproductive potential and breeding seasons of fishes is the understanding of fecundity and gonadosomatic index. The present investigation reveals a significant linear relationship between fecundity vs. body weight $(r=0.95)$ vs. ovary weight $(r=0.88)$ vs. ovary length $(r=0.74)$ vs. total length $(0.60)$. The value of ' $r$ ' between fecundity and body weight $(\mathrm{r}=0.95)$ shows very significant positive correlation followed by ovary weight $(\mathrm{r}=0.88)$. However it exhibits a moderate correlation with total length $(\mathrm{r}=0.60)$ of the species which was 
also earlier observed in Puntius sophore [14], Cirrhinus reba [15] and Mystus bleekeri [16]. The mean \pm SD of fecundity gradually increases from the month of April $(3947.91 \pm 506.42)$ exhibiting its highest peak in the month of June (10957.47 \pm 3031.49$)$ and thereafter it gradually declining from the month of July (6021.02 \pm 1571.54). Fecundity of fishes changes remarkably with the changes in some of the environment factors such as temperature, salinity and oxygen [17]. Similarly during the study period the value of correlation coefficient between fecundity vs. body weight $(\mathrm{r}=0.95)$ vs. ovary weight $(\mathrm{r}=0.88)$ vs. total length $(0.60)$ vs. gonadosomatic index $(r=0.51)$ is found to be the highest in the month of June and then it value decreases. The gonadosomatic index or maturity index is an indirect method for estimating spawning season of a species. The rise and fall in GSI\% and structural changes in the gonads besides progression of the size of the ova is an indicator of spawning season [18]. The mean \pm SD of gonadosomatic index increases from April $(6.42 \pm 2.52)$ to reach the highest peak in the month of June $(9.43 \pm 1.61)$ thereafter the GSI\% is found to be decreased in the month July $(8.63 \pm$ 2.63). The value of GSI\% is normally found highest during May - June when majority of the fishes attain their maturity [19]. The variation of GSI\% in Clarias magur is triggered by seasonal change in monsoon and variation of climatic condition. Depending on the monsoon and differential climatic condition, the variation of GSI\% value in the same species may take place [20]. The GSI\% of fishes increases with the maturation gonad in fishes [21]. In Assam, temperature and rainfall start to rise from the month of March and giving its peak in the month of June. The result shows that the ovary of Clarias magur starts to mature following increase of temperature and rainfall. The graphical representation (Fig. 1a -1d) shows that the species breeds only one breeding season commencing from April culminating in the month of June and it starts declining from July in agro climatic condition of Assam.

\section{Conclusion:}

The present study indicates that in Assam Clarias magur responds to one breeding season for a short duration while showing favourable and best breeding performance during April to June. This information is considered valuable for commercial production of the species. The more attention is needed for induced breeding and culture of the species in captivity as a measure for its cultural conservation and commercial exploitation after following the clear protocol.

References

[1] HH. Ng and M. Kottelat, The identity of Clarias batrachus (Linnaeus, 1758), with the designation of a neotype (Teleostei: Clariidae). Zoological Journal of the Linnean Society, 153, 2008, 725-732.

[2] W. Vishwanath :Clarias magur: IUCN 2012.IUCN Red List of Threatened Species. Version 2012.2.www.iucnredlist.org

[3] G.V. Nikolsky, Ecology of Fishes (London: Academic Press London, 1963) 352.

[4] K.F. Lagler, T.E. Bardach and R.R. Miller, Ichthyology (Inc. New York, London, Sydney, John Willey \& Sons, 1967) 271-274

[5] K.F. Lagler, Ennumeration of fish eggs, In freshwater fishery biology, $2^{\text {nd }}$ Ed. ( Dubuque: W.M. Brown company publishers, 1956) 106-110.

[6] S. Doha and M.A. Hye, Fecundity of the Padma river Hilsa ilisha (Ham. J.) Pak. Sci, 22, 1970, 176-183.

[7] A.C. Simpson, The fecundity of the plaice. Fish. Invest. London, 17, 1951, 1-27.

[8] M.C. Healey and W.R. Heard, Inter -and intra-population variation in the fecundity of Chinook salmon (Oncorhynchustshawytscha) and its relevance to life history theory, Can. J. Fish. Aquat. Sci.,41, 1984, 476-483.

[9] T.D. Beacham and C.B. Murray, Adaptive variation in body size, age, morphology, egg size and developmental biology of chum salmon (Oncorhynchusketa) in British Columbia, Can. J. Fish.Aquat. Sci., 44, 1987, 244-261.

[10] K.F. Lagler, Ennumeration of fish eggs, In freshwater fishery biology, $2^{\text {nd }}$ Ed. ( Dubuque: W.M. Brown company publishers, 1956) 106-110.

[11] S. Doha and M.A. Hye, Fecundity of the Padma river Hilsa ilisha (Ham. J.) Pak. Sci, 22, 1970, 176-183.

[12] H.P. Das, The fecundity of Grey mullet Mugilcephalus L. along the goa coast, Mohasagar, Bull. Nam. Inst, Ocean, 10 (1\& 2),1977, 79-82.

[13] M.A. Hossain, A. Taleb and M.H. Rahman, Reproduction and fecundity of Ompok pabda (Ham.)Bangladesh J. Sci. Res, 101, 1992, 49-52.

[14] H.K. Phukon and S.P. Biswas, Observation on the Maturity Index and Fecundity of Puntius sophore (Ham-Buch) from Upper Assam, ASIAN J.EXP. BIOL.SCI. VOL 3 (1), 2012, 247-250.

P.K. Lashari, N.T. Narejo, M.Y. Laghari and A.M. Mastoi, Studies on the Gonadosomatic Index and Fecundity of a Carp Cirrhinusreba (Hamilton) from Fishponds of District Jacobabad, Sindh, Pakistan,Pakistan J. Zool, vol. 39(2), 2007, 95-98.

[16] A.S.M. Musa and A.S. Bhuiyan, Fecundity on Mystus bleekeri (Day, 1877) from the River Padma Near Rajshahi City, Turkish journal of Fisheries and Aquatic Sciences, 7, 2007, 161-162.

[17] T.B and E. Braum, Eggs and Early Life History. IBP Hand Book No. 3, (Oxford: Blackwell Scientific Publication, 1978) 106

[18] A.K. saikia, S.S. Abujam and S.P. Biswas, Reproductive biology of Channa punctatus (Bloch) from paddy field of Sivasagar, Assam, International journal of current research vol. 5, Issue, 03, 2013, 542-546.

[19] A.K. saikia, S.S. Abujam and S.P. Biswas, Reproductive biology of Channa punctatus (Bloch) from paddy field of Sivasagar, Assam, International journal of current research vol. 5, Issue, 03, 2013, 542-546.

[20] S.P. Biswas, Studies on Some Aspects of the biology of Labeo pangusia and Labeo dero From North eastern India, doctoral diss., North- eastern Hill University, shilling, 1982.

[21] M.V. Gaikwad, V.R. more, S.M. Shingare, D.K. Hiwarale and Y.K. Khillare, Study on Gonadosomatic and Fecundity Relationshipship in Air breathing fish Channa gachua (Ham.) From Godavari near Aurangabad, African Journal of Basic \&Applied Sciences 1(5-6), 2009., 93-95. 